\title{
Research on Establishment of an Index System for the Low-carbon Industrial Parks in Wuhan City
}

\author{
Yanyan Huang, Jingjing Wang \\ ${ }^{1}$ School of Civil Engineering and Architecture, Hubei University of Technology
}

\begin{abstract}
Along with an upsurge in the construction of eco-industrial parks in China, research on the appraisal system of industrial parks has become a focus of public concern. With low-carbon industrial park as an object of study, this paper proposes a setup procedure and specific construction method for index system based upon such technical methods as preliminary index selection, secondary screening and expert consultation, to guide the construction of low-carbon industrial parks in Wuhan City.
\end{abstract}

\section{Introduction}

Developing low-carbon industrial park is an important measure for carrying out scientific outlook on development, coping with climatic change, developing low-carbon economy and boosting energy saving and emission reduction, and an inevitable choice to promote urban and rural construction quality and construct livable towns. The index system of low-carbon park construction is an effective tool to measure, describe, judge, evaluate and predict the sustainable development situation of this region, which can be used to control and guide the planning and construction of low-carbon industrial parks as well as the final-period operation and management of low-carbon industrial parks. Therefore, to develop an assessment system for low-carbon industrial parks is of vital importance to the development of low-carbon industrial parks ${ }^{[1]}$.

\section{Setup Procedure of Index System}

For the setting of an index system for Wuhan's lowcarbon industrial parks, there are three steps, which are index selection, secondary screening and final determination. See Fig 1. for concrete procedures.

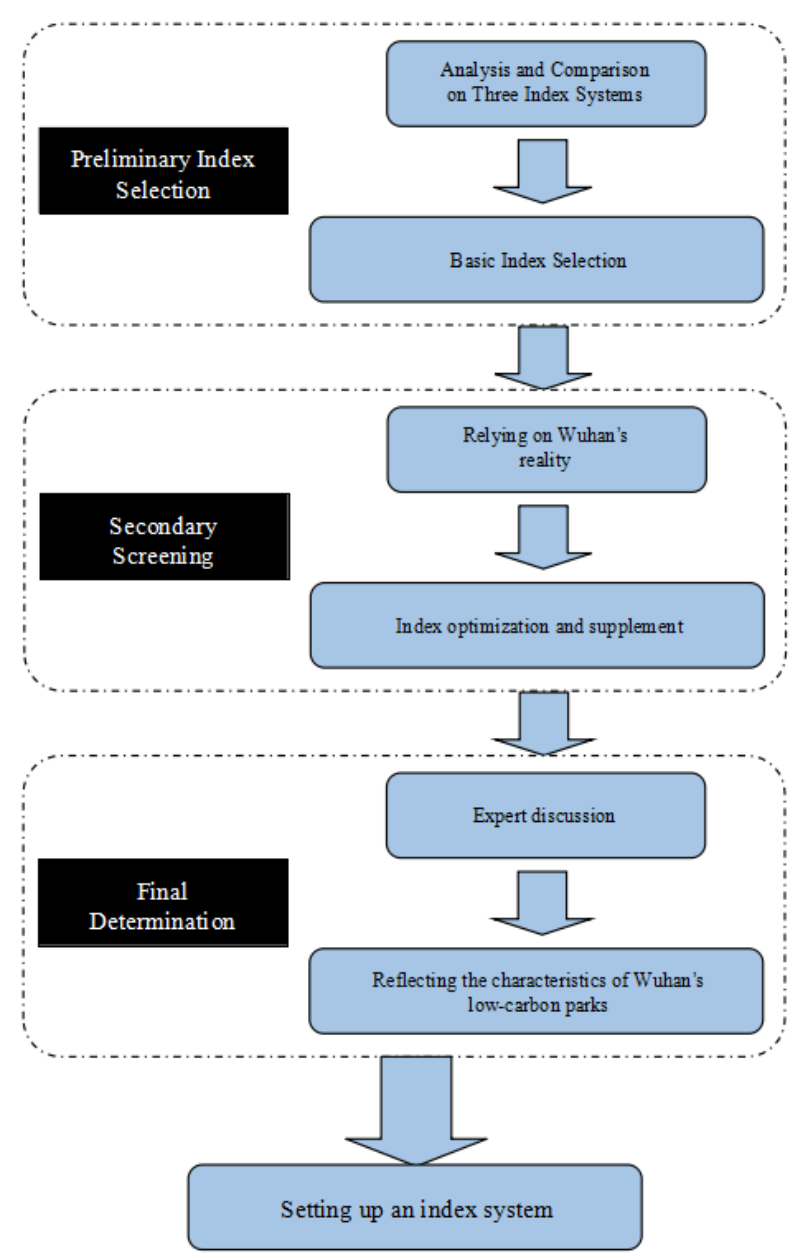

Fig 1. construction procedure of index system

\section{Concrete Construction of Index System}

\subsection{Preliminary Index Selection}

\subsubsection{Analysis and Comparison on Three Index Systems}

To establish an index system for the low-carbon industrial parks in Wuhan City, the research group learned such three documents related to the index system 
and construction guideline of industrial parks (hereinafter referred to as index system) as Transformation of China Industrial Development Zones: Towards a Low Carbon Future $^{[2]}$ compiled by The Administrative Centre for China's Agenda 21 (ACCA21) and Institute for Sustainable Communities (ISC), Research Report on the Appraisal System of Low-Carbon Industrial Parks in Hubei Province ${ }^{[3]}$ made by Research Center for LowCarbon Economy and Technology of Hubei University of Technology, and Guidelines for the Construction of Green Ecological Urban Areas in Wuhan City established by Wuhan Municipal Office of Building Energy Efficiency.

Analysis and comparison show they have the same research background_-global climate warming caused by greenhouse gas emission has posed a serious challenge to human existence and development. Their differences are mainly reflected in the following two aspects:

(1)Difference in Scope of Application

The appraisal index system of low carbon development in China's industrial parks is researched at the national level, the appraisal index system of Hubei's low-carbon industrial parks is researched at the provincial level, and the appraisal index system of Wuhan's green ecological urban areas is researched at the municipal level. The scope of application of each index system is illustrated in Tab 1.

Tab 1. a comparison between the three index systems in scope of application

\begin{tabular}{|c|c|c|c|}
\hline Index system & Object & $\begin{array}{c}\text { Scope of application } \\
\text { Applicable to } \\
\text { industrial } \\
\text { parks } \\
\text { comprehensive parks } \\
\text { as well as } \\
\text { manufacturing-led } \\
\text { county-level and } \\
\text { district-level } \\
\text { administrative regions }\end{array}$ & Level \\
\hline $\begin{array}{c}\text { Hubei's low- } \\
\text { carbon } \\
\text { industrial } \\
\text { parks }\end{array}$ & $\begin{array}{c}\text { Industrional } \\
\text { al park }\end{array}$ & $\begin{array}{c}\text { Applicable to the } \\
\text { industrial parks that } \\
\text { cover an area of 4km² } \\
\text { to 80km² (an industrial } \\
\text { park can be divided } \\
\text { into several ones if its } \\
\text { area exceeds the upper } \\
\text { limit) }\end{array}$ & Provincial \\
\hline $\begin{array}{c}\text { Wuhan's } \\
\text { green } \\
\text { ecological } \\
\text { urban areas }\end{array}$ & $\begin{array}{c}\text { Green } \\
\text { ecologi } \\
\text { cal } \\
\text { urban } \\
\text { area }\end{array}$ & $\begin{array}{c}\text { The green ecological } \\
\text { urban area } \\
\text { demonstrative projects } \\
\text { whose planned area } \\
\text { isn't less than 1.5 } \\
\text { square kilometers }\end{array}$ & Municipal \\
\hline
\end{tabular}

(2)Difference in Number of Indexes

The appraisal index system of low carbon development in China's industrial parks falls into 4 criterion layers, 7 secondary indexes and 23 third-grade indexes; the appraisal index system of Hubei's lowcarbon industrial parks falls into 3 criterion layers, 5 secondary indexes and 4 third-grade indexes; the appraisal index system of Wuhan's green ecological urban areas falls into 4 criterion layers, 14 secondary indexes and 108 third-grade indexes; An analysis and comparison on them is shown in Fig 2.

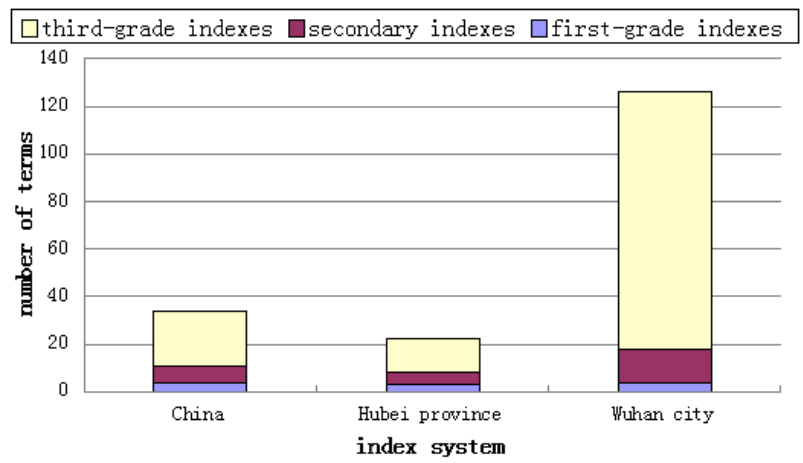

Fig 2. a comparison between the three index systems in number of indexes

\subsubsection{Basic Index Selection}

After research and analysis, the research group finally selected 32 basic indexes, specifically including building density, plot ratio, park greening rate, green building ratio, new building energy-saving standard enforcement, power consumption per industrial added value, elasticity coefficient of industrial comprehensive energy consumption, land coverage ratio of industrial regional administrative office and living service facilities, proportion of second-class industrial land in industrial land, proportion of the enterprises that have passed ISO14001 certification, scale of green industrial architecture, share of new energy vehicles in the vehicles for public use, proportion of green travel, share of green electric power consumption in total electric power consumption, comprehensive utilization ratio of industrial exhaust heat, ratio of renewable energy, intelligent microgrid technology, energy consumption per unit of GDP, energy-consuming reduction rate per unit of GDP, carbon dioxide emission intensity per unit of GDP, carbon dioxide emission intensity reduction rate per unit of GDP, proportion of the enterprises within park that have finished greenhouse gas verification, comprehensive utilization ratio of industrial solid wastes, classification and collection rate of municipal solid wastes, recycle rate of industrial water, centralized treatment ratio of domestic sewage, utilization rate of nontraditional water source, setup of low-carbon industrial park leadership and operating mechanism, carbon information statistics and disclosure, green building design, energy assessment \& popularization rate, and establishment of a special fund for low carbon development.

\subsection{Secondary Screening}

Considering that the construction of a low-carbon park involves in many links, such as society, economy and environment, and according to a comprehensive consideration of the composition characteristics of the compound system in Wuhan's industrial parks, we divide index system into three levels, including 4 first-grade indexes: planning layout and land utilization, resource utilization and greenhouse gas management, circular economy and environmental protection, and park management and guarantee mechanism;10secondary 
indexes: land intensive use, building energy efficiency, industrial energy efficiency, traffic energy efficiency, resource utilization, greenhouse gas management, solid waste, water, management system construction, financial security(see Fig 3.); third-grade indexes: 32 ones.

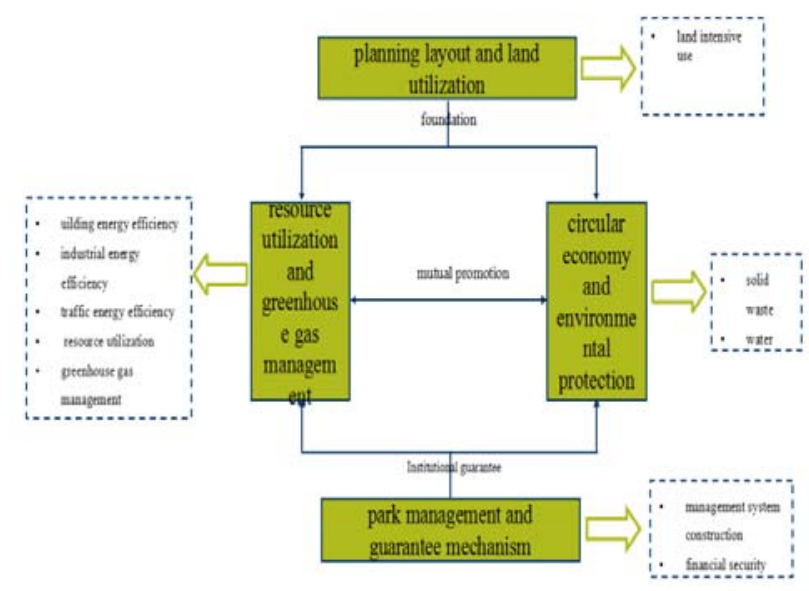

Fig 3. the relationship between first-grade indexes and secondary indexes

Wuhan has a long history and a culture of great splendor. It was named Xiarui and Ezhu in the ancient times, known as an important cradle of Jingchu Culture, and now is an important industrial base. Some indicators, including utilization and exploitation rate of underground space, encouragement to the development and reuse of abandoned site, area scale of permeable pavement in rigid pavement, road network density and slow lane density, etc., are added according to Wuhan's practical development situation (see Tab 2.).

Tab 2. basis for the selection of the indexes added

\begin{tabular}{|c|c|}
\hline Basic index & Basis for selection \\
\cline { 1 - 2 } $\begin{array}{c}\text { Utilization and exploitation } \\
\text { rate of underground space }\end{array}$ & $\begin{array}{c}\text { Both are an important } \\
\text { measure for intensive usage of } \\
\text { land } \\
\begin{array}{c}\text { Encouragement to the } \\
\text { development and reuse of } \\
\text { abandoned site }\end{array}\end{array}$ \\
\hline Area scale of permeable \\
pavement in rigid pavement & $\begin{array}{c}\text { As a pilot sponge city in } \\
\text { China, Wuhan requires } \\
\text { economical utilization of } \\
\text { water resources }\end{array}$ \\
\hline Road network density & $\begin{array}{c}\text { Traffic is a key field in low- } \\
\text { carbon transition, and this } \\
\text { index reflects the status of } \\
\text { public travel and transport } \\
\text { infrastructure }\end{array}$ \\
\hline
\end{tabular}

In Research Report on the Appraisal System of LowCarbon Industrial Parks in Hubei Province made by Research Center for Low-Carbon Economy and Technology of Hubei University of Technology there is included low-carbon park planning, inclusive of special traffic planning and special energy planning; in Guidelines for the Construction of Green Ecological Urban Areas in Wuhan City established by Wuhan Municipal Office of Building Energy Efficiency there are included special low-carbon planning, special traffic planning, special energy planning, special water resources planning and special green architectural planning. Thus it can be seen that attention should be paid to special planning in index system. So, this content is added to the index system of Wuhan's low-carbon industrial parks. Namely, low-carbon park planning, including special green architectural planning, special traffic planning for crawlerway, parking and public transportation, special energy planning for comprehensive utilization of various energy resources, water resource comprehensive utilization planning for comprehensive utilization of various water resources, and park low-carbon development planning have been made, supporting policies have been formulated for promotion of low carbon development, and action objectives, key tasks and specific measures have been put forward clearly for carbon emission control ${ }^{[4]}$.

\subsection{Final Determination}

On June 11, 2015 in Wuhan, Wuhan Municipal Development and Reform Commission organized the convening of a seminar on "Research of Standard System Construction and Development Pattern for Low-carbon Industrial Parks in Wuhan City”, a low carbon task item of 2014 under the research of Hubei University of Technology. The leaders of the relevant units, such as Wuhan Environment Protection Sciences Research Institute, Wuhan Association for Circular Economics, Operation Offices under People’s Bank of China Wuhan Branch, Hubei Emission Exchange and Hubei Provincial Development and Reform Commission, and the expert groups of the expert organizations concerned were invited to the seminar. At the seminar, 38 indexes that survived preliminary selection and secondary screening were adjusted based upon the particular case according to the features and requirements of Wuhan's low-carbon parks, the goal of each index set and the information to be reflected were made clear, the rationality and operability of the indexes were further considered, and scientific indexes were added, to finally perfect the index system.

The expert groups listened to the research group's report, and expressed a view based on a serious inquiry and discussion that a general framework and list of indexes had been established for the standard system of Wuhan's low-carbon industrial parks, and the report had a clear and basically rational structure. Meanwhile, they suggested enhancing investment intensity, normatively implementing the two basic indicators of environmental impact assessment, and further optimizing and improving the index system.

After the seminar, the research group took the experts' advice, further improving and modifying the index system, and finally dividing the index system into three levels, including 4 first-grade indexes: planning layout and land utilization, resource utilization and greenhouse gas management, circular economy and environmental protection, and park management and guarantee mechanism; 10 secondary indexes: land intensive use, building energy efficiency, industrial 
energy efficiency, traffic energy efficiency, resource utilization, greenhouse gas management, solid waste, water, management system construction, financial security (see Tab 3.); third-grade indexes: 40 ones.

Tab 3. index system of Wuhan's low-carbon industrial parks

\begin{tabular}{|c|c|c|c|}
\hline \multicolumn{2}{|c|}{ Indicators stratified } & \multirow{2}{*}{$\begin{array}{c}\text { The } \\
\text { serial } \\
\text { number }\end{array}$} & \multirow[b]{2}{*}{ Index items } \\
\hline Stair & $\begin{array}{c}\text { The } \\
\text { secondary }\end{array}$ & & \\
\hline \multirow{6}{*}{$\begin{array}{l}\text { Planning } \\
\text { layout and } \\
\text { land } \\
\text { utilization }\end{array}$} & \multirow{6}{*}{$\begin{array}{l}\text { Lland } \\
\text { intensive } \\
\text { use }\end{array}$} & 1 & Building density \\
\hline & & 2 & Plot ratio \\
\hline & & 3 & $\begin{array}{l}\text { Encouragement to the } \\
\text { development and reuse } \\
\text { of abandoned site }\end{array}$ \\
\hline & & 4 & $\begin{array}{c}\text { Utilization and } \\
\text { exploitation rate of } \\
\text { underground space }\end{array}$ \\
\hline & & 5 & Park greening rate \\
\hline & & 6 & Investment intensity \\
\hline \multirow{18}{*}{$\begin{array}{l}\text { Resource } \\
\text { utilization } \\
\text { and } \\
\text { greenhous } \\
\text { e gas } \\
\text { managem } \\
\text { ent }\end{array}$} & \multirow{3}{*}{$\begin{array}{l}\text { Building } \\
\text { energy } \\
\text { efficiency }\end{array}$} & 7 & Green building ratio \\
\hline & & 8 & $\begin{array}{l}\text { Area scale of permeable } \\
\text { pavement in rigid } \\
\text { pavement }\end{array}$ \\
\hline & & 9 & $\begin{array}{l}\text { New building energy- } \\
\text { saving standard } \\
\text { enforcement }\end{array}$ \\
\hline & \multirow{6}{*}{$\begin{array}{l}\text { Industrial } \\
\text { energy } \\
\text { efficiency }\end{array}$} & 10 & $\begin{array}{l}\text { Power consumption per } \\
\text { industrial added value }\end{array}$ \\
\hline & & 11 & $\begin{array}{c}\text { Elasticity coefficient of } \\
\text { industrial } \\
\text { comprehensive energy } \\
\text { consumption }\end{array}$ \\
\hline & & 12 & $\begin{array}{l}\text { Land coverage ratio of } \\
\text { industrial Regional } \\
\text { administrative office } \\
\text { and living service } \\
\text { facilities } \\
\end{array}$ \\
\hline & & 13 & $\begin{array}{l}\text { Proportion of second- } \\
\text { class industrial land in } \\
\text { industrial land }\end{array}$ \\
\hline & & 14 & $\begin{array}{c}\text { Proportion of the } \\
\text { enterprises that have } \\
\text { passed ISO14001 } \\
\text { certification }\end{array}$ \\
\hline & & 15 & $\begin{array}{c}\text { Scale of green industrial } \\
\text { architecture }\end{array}$ \\
\hline & \multirow{4}{*}{$\begin{array}{c}\text { Traffic } \\
\text { energy } \\
\text { efficiency }\end{array}$} & 16 & $\begin{array}{c}\text { Share of new energy } \\
\text { vehicles in the vehicles } \\
\text { for public use }\end{array}$ \\
\hline & & 17 & $\begin{array}{c}\text { Proportion of green } \\
\text { travel }\end{array}$ \\
\hline & & 18 & Road network density \\
\hline & & 19 & Slow lane density \\
\hline & \multirow{5}{*}{$\begin{array}{l}\text { Resource } \\
\text { utilization }\end{array}$} & 20 & $\begin{array}{c}\text { Share of green electric } \\
\text { power consumption in } \\
\text { total electric power } \\
\text { consumption }\end{array}$ \\
\hline & & 21 & $\begin{array}{c}\text { Comprehensive } \\
\text { utilization ratio of } \\
\text { industrial exhaust heat }\end{array}$ \\
\hline & & 22 & $\begin{array}{c}\text { Ratio of renewable } \\
\text { energy }\end{array}$ \\
\hline & & 23 & $\begin{array}{l}\text { Intelligent micro-grid } \\
\text { technology }\end{array}$ \\
\hline & & 24 & $\begin{array}{l}\text { Energy consumption per } \\
\text { unit of GDP }\end{array}$ \\
\hline
\end{tabular}

\begin{tabular}{|c|c|c|c|}
\hline & & 25 & $\begin{array}{l}\text { Energy-consuming } \\
\text { reduction rate per unit } \\
\text { of GDP }\end{array}$ \\
\hline & \multirow{3}{*}{$\begin{array}{l}\text { Greenhouse } \\
\text { gas } \\
\text { manageme } \\
\text { nt }\end{array}$} & 26 & $\begin{array}{c}\text { Carbon dioxide } \\
\text { emission intensity per } \\
\text { unit of GDP }\end{array}$ \\
\hline & & 27 & $\begin{array}{c}\text { Carbon dioxide } \\
\text { emission intensity } \\
\text { reduction rate per unit } \\
\text { of GDP }\end{array}$ \\
\hline & & 28 & $\begin{array}{l}\text { Proportion of the } \\
\text { enterprises within park } \\
\text { that have finished } \\
\text { greenhouse gas } \\
\text { verification }\end{array}$ \\
\hline \multirow{5}{*}{$\begin{array}{l}\text { Circular } \\
\text { economy } \\
\text { and } \\
\text { environm } \\
\text { ental } \\
\text { protection }\end{array}$} & \multirow{2}{*}{ Solid waste } & 29 & $\begin{array}{c}\text { Comprehensive } \\
\text { utilization ratio of } \\
\text { industrial solid wastes }\end{array}$ \\
\hline & & 30 & $\begin{array}{c}\text { Classification and } \\
\text { collection rate of } \\
\text { municipal solid wastes }\end{array}$ \\
\hline & \multirow{3}{*}{ Water } & 31 & $\begin{array}{l}\text { Recycle rate of } \\
\text { industrial water }\end{array}$ \\
\hline & & 32 & $\begin{array}{c}\text { Centralized treatment } \\
\text { ratio of domestic } \\
\text { sewage } \\
\end{array}$ \\
\hline & & 33 & $\begin{array}{c}\text { Utilization rate of } \\
\text { nontraditional water } \\
\text { source }\end{array}$ \\
\hline \multirow{7}{*}{$\begin{array}{c}\text { Park } \\
\text { managem } \\
\text { ent and } \\
\text { guarantee } \\
\text { mechanis } \\
\text { m }\end{array}$} & \multirow{6}{*}{$\begin{array}{c}\text { Manageme } \\
\text { nt system } \\
\text { constructio } \\
\text { n }\end{array}$} & 34 & $\begin{array}{c}\text { Setup of low-carbon } \\
\text { industrial park } \\
\text { leadership and operating } \\
\text { mechanism } \\
\end{array}$ \\
\hline & & 35 & $\begin{array}{c}\text { Carbon information } \\
\text { statistics and disclosure }\end{array}$ \\
\hline & & 36 & $\begin{array}{c}\text { Low-carbon park } \\
\text { planning }\end{array}$ \\
\hline & & 37 & Green building design \\
\hline & & 38 & $\begin{array}{c}\text { Normative } \\
\text { implementation of } \\
\text { environmental impact } \\
\text { assessment }\end{array}$ \\
\hline & & 39 & $\begin{array}{c}\text { Energy assessment \& } \\
\text { popularization rate }\end{array}$ \\
\hline & $\begin{array}{l}\text { Financial } \\
\text { security }\end{array}$ & 40 & $\begin{array}{l}\text { Establishment of a } \\
\text { special fund for low } \\
\text { carbon development }\end{array}$ \\
\hline
\end{tabular}

\section{Conclusions}

The 40 indexes retained after preliminary, secondary screening, and final determination contain abundant information of low-carbon park construction. In particular, the special indexes added to park construction in Wuhan City are better able to guide the establishment of low-carbon industrial parks. This index system can help reflect the scientific development concept of knowledge economy, circular economy and ecological economy, and realize the overall optimization, coordination and continuance of social benefits, economic benefits and environmental benefits ${ }^{[5]}$, able to promote the rapid development of low-carbon industrial parks in Wuhan City, and provide reference for the industrial parks in other places. 


\section{Acknowledgements}

A Study on the Technology Guide of Constructing Lowcarbon City in Wuhan based on the Climatic Characteristics(D20141402)

A Study on the Standard System Construction and Development Mode in the Low-carbon Industrial Park in Wuhan(WHJT-CZH—2014-1141)

\section{References}

[1] Cheng Beibei, Wang Peng \& Zhao Daiqing. Research on the Planning Method and Appraisal Index System of Low-carbon Industrial Parks[J]. Ecological Economy, 2013 (5): 126-128.

[2] Pan Tao, Cao Xiaojing \& Geng Yu, et al. Report on Low Carbon Development in China's Industrial Parks[M]. Institute for Sustainable Communities, (2012).

[3] Zhou Juan. Research on the Appraisal Index System of Low-carbon Industrial Parks-a Case Study of Hubei Province[D]. Huazhong University of Science and Technology, (2013).

[4] Lei Ming. Research on the Comprehensive Evaluation of Low-carbon Industrial Parks[D]. Huazhong University of Science and Technology, (2010).

[5] Xu Hong. Establishment of a Scientific Index System for Urban Sustainable Development[J]. Urban Studies, 2004 (3): 49. 